\title{
Age-related macular degeneration
}

\author{
Hanna R Coleman, Chi-Chao Chan, Frederick L Ferris III, and Emily Y Chew \\ Division of Epidemiology and Clinical Research, (H R Coleman MD, F L Ferris III MD, E Y Chew \\ $\mathrm{MD}$ ), and Laboratory of Immunology (C-C Chan MD), National Eye Institute, National Institutes of \\ Health, Bethesda, MD, USA
}

\begin{abstract}
Age-related macular degeneration is the leading cause of blindness in elderly populations of European descent. The most consistent risk factors associated with this ocular condition are increasing age and cigarette smoking. Genetic investigations have shown that complement factor $\mathrm{H}$, a regulator of the alternative complement pathway, and LOC387715/HtrA1 are the most consistent genetic risk factors for age-related macular degeneration. Although the pathogenesis of this disease is unknown, oxidative stress might have an important role. Treatment with antioxidant vitamins and zinc can reduce the risk of developing advanced age-related macular degeneration by about a quarter in those at least at moderate risk. Intravitreal injections of ranibizumab, a monoclonal antibody that inhibits all forms of vascular endothelial growth factor, have been shown to stabilise loss of vision and, in some cases, improve vision in individuals with neovascular age-related macular degeneration. These findings, combined with assessments of possible environmental and genetic interactions and new approaches to modulate inflammatory pathways, will hopefully further expand our ability to understand and treat age-related macular degeneration.
\end{abstract}

\section{Introduction}

Age-related macular degeneration is the most common cause of visual impairment in individuals over the age of 55 years in developed countries. ${ }^{1}$ The disease, in its early stages, develops slowly and asymptomatically over a number of years. Although the definition of agerelated macular degeneration differs in various studies, the condition is generally characterised by extensive drusen, often associated with pigmentary abnormalities. Drusen are visualised as whitish yellow deposits under the retinal pigment epithelium and neurosensory retina. In elderly individuals, a restricted number of small drusen $(<63 \mu \mathrm{m}$ in diameter) are common; such patients are not deemed to have age-related macular degeneration because they are at low risk of developing vision loss. ${ }^{2}$ Although drusen are the common denominator for age-related macular degeneration, the disease has been subdivided into three categories on the basis of the risk of developing vision loss (panel, figure 1, figure 2, and figure 3).

Two classification schemes have been developed to estimate the risk of progression from the early stages of age-related macular degeneration to the advanced stage. The first is a detailed scheme that generally needs careful photographic review for implementation. ${ }^{7}$ The second is a simplified scale that is easy to use clinically. ${ }^{8}$ In both schemes the risk of developing the advanced forms of age-related macular degeneration is directly associated with the extent of

Correspondence to: Dr Emily Y Chew, Division of Epidemiology and Clinical Research, National Eye Institute/National Institutes of Health, Building 10, CRC, Room 3-2531, 10 Center Drive, MSC-1204, Bethesda, MD 20892-1204, USA echew@ nei.nih.gov.

Conflict of interest statement

FLF is one of the inventors on US patent 6660297 (Nutritional supplement to treat macular degeneration), owned by Bausch and Lomb. He has assigned his interest in the patent to the US Government and receives government compensation. All other authors declare that they have no conflict of interest. 
the drusen and the amount of hypopigmentary or hyperpigmentary changes of the retinal pigment epithelial layer. For example, based on the simplified scale, individuals with both large drusen and the pigmentary changes in both eyes, or with these lesions in one eye and advanced age-related macular degeneration in the other, have about a $50 \%$ risk of developing advanced age-related macular degeneration in 5 years. ${ }^{8}$ The pathogenesis of age-related macular degeneration is not well known, although a number of theories have been put forward, including oxidative stress, mitochondrial dysfunction, and inflammatory processes. ${ }^{9-13}$

\section{Epidemiology}

Age-related macular degeneration accounts for more than $54 \%$ of all vision loss in the white population in the USA. ${ }^{1}$ An estimated 8 million Americans are affected with early age-related macular degeneration, of whom over 1 million will develop advanced age-related macular degeneration within the next 5 years. ${ }^{14}$ In the UK, age-related macular degeneration is the cause of blindness in almost $42 \%$ of those who go blind aged 65-74 years, almost two-thirds of those aged 75-84 years, and almost three-quarters of those aged 85 years or older. ${ }^{15}$

Data pooled from three population-based studies—-the Beaver Dam Eye Study, the Rotterdam Study, and the Blue Mountains Eye Study — have estimated the prevalence of advanced agerelated macular degeneration to be $0 \cdot 2 \%$ in those aged 55-64 years, increasing to $13 \%$ in those older than 85 years. ${ }^{16}$ These three large population-based studies have found that the incidence of advanced age-related macular degeneration increases with age, as does the development of large drusen and pigmentary changes. The Blue Mountains Eye Study estimated the overall 5year incidence of advanced age-related macular degeneration to be $1.1 \%$; increasing from $0 \%$ in individuals under 60 years of age to $5.4 \%$ in those aged 80 years or older. The overall 5year incidence of the development of large drusen or pigmentary changes was $8.7 \%$, ranging from $3.2 \%$ in those aged less than 60 years to $18.3 \%$ in those aged $70-79$ years and $14.8 \%$ in those older than 80 years. ${ }^{17,18}$ The 15 -year incidence of neovascular macular degeneration in the Beaver Dam Eye Study ranged from $0.4 \%$ in individuals under 55 years of age to $4.4 \%$ in those older than 75 years; the 15-year incidence of soft indistinct drusen ranged from $4.7 \%$ to $16.3 \%$ in the same age-groups. ${ }^{19}$ The 5-year progression rate to advanced age-related macular degeneration in individuals who had intermediate age-related macular degeneration and who were 80 years or older was $42 \%$ in the Rotterdam Study. ${ }^{20}$ The 5 -year progression rate to advanced age-related macular degeneration in another population-based study-the Visual Impairment Project from Melbourne, Australia—ranged from $0 \%$ in people aged 60 years and younger to $6.3 \%$ in those 80 years and older. ${ }^{21}$

\section{Search strategy and selection criteria}

We searched PubMed and Web of Knowledge for the term "age-related macular degeneration". Most publications were from the past 8 years, but we also included older references that were commonly referenced or highly regarded. We limited our search to English language publications only.

\section{Panel: Classification of age-related macular degeneration}

\section{Early age-related macular degeneration}

Multiple small drusen $(<63 \mu \mathrm{m})$ or intermediate drusen $(\geq 63 \mu \mathrm{m}$ and $<125 \mu \mathrm{m})$ with no evidence of advanced age-related macular degeneration. 


\section{Intermediate age-related macular degeneration}

Extensive intermediate drusen or large drusen $(\geq 125 \mu \mathrm{m})$ with no evidence of advanced agerelated macular degeneration (figure 1).

\section{Advanced age-related macular degeneration}

Advanced age-related macular degeneration is characterised by the presence of one or other of geographic atrophy or neovascular age-related macular degeneration.

Geographic atrophy is the presence of a discrete area of retinal depigmentation at least 175 $\mu \mathrm{m}$ in diameter with a sharp border and visible choroidal vessels in the absence of neovascular age-related macular degeneration in the same eye (figure 2). ${ }^{3}$ Geographic atrophy results from the continued loss of retinal pigment epithelium, with the eventual development of focal areas of total loss of the retina, retinal pigment epithelium, and the small blood vessels directly under the epithelium. The disease is generally slowly progressive. Central geographic atrophy involves the centre of the macula.

Neovascular age-related macular degeneration is characterised by the serous or haemorrhagic detachment of either the retinal pigment epithelium or sensory retina, the presence of subretinal fibrous tissue, or minimal subretinal fibrosis (figure 3 ). ${ }^{3}$

Neovascularisation developing under the retina, which can leak fluid or bleed. Onset of vision loss is acute. Neovascular age-related macular degeneration is the most common cause of severe central visual loss. ${ }^{4-6}$

\section{Risk factors}

Age is the strongest risk factor for age-related macular degeneration; all population-based studies confirm that the prevalence of age-related macular degeneration increases with age in white individuals. ${ }^{3,22-27}$ Female sex may be a risk factor in individuals aged over 75 years, 16 with the relative risk for neovascular age-related macular degeneration in women possibly as much as twice that observed in age-matched men. However, in regression models that adjust for age as a continuous variable, rather than by decade, the effect of sex on risk of age-related macular degeneration was not statistically significant. ${ }^{17}$

Results from a number of case-control studies, ${ }^{28-33}$ population-based studies, ${ }^{34-36}$ and prospective studies of both physicians ${ }^{37}$ and nurses ${ }^{38}$ strongly confirm cigarette smoking as a risk factor for age-related macular degeneration. There exists a direct association between the risk of developing advanced age-related macular degeneration with the number of cigarettes smoked. ${ }^{29,39}$ Only one epidemiological study failed to find an association between smoking and age-related macular degeneration. ${ }^{40}$ The mechanism by which smoking might affect the retina is unknown, although oxidative insults to the retina have been implicated.

Age-related macular degeneration is more common in white individuals than in people of other ethnic origin. ${ }^{21,41,42}$ Data from the Barbados Eye Study, ${ }^{42}$ the Baltimore Eye Study, ${ }^{25}$ the Age-Related Eye Disease Study (AREDS), ${ }^{28}$ and the National Health and Nutrition Examination Survey III (NHANES III) ${ }^{41}$ have shown that drusen are seen at similar frequencies in white and non-white individuals. However, these studies also show a definite increased prevalence of advanced age-related macular degeneration in white people compared with others. It is postulated that increased levels of melanin could increase the free-radical scavenging potential of the retinal pigmented epithelium and Bruch's membrane, thereby protecting against the risk of advanced age-related macular degeneration. More recently, the Multi-ethnic Study of Atherosclerosis showed the prevalence of age-related macular degeneration in individuals aged $45-85$ years to be $2.4 \%$ in African-American people, $4.2 \%$ in Hispanic individuals, $4.6 \%$ in Chinese, and $5.4 \%$ in white individuals. ${ }^{43}$ The neovascular 
form of age-related macular degeneration was highest in Chinese individuals, compared with white people. ${ }^{31}$ These ethnic differences in prevalence need further validation.

Increasing evidence suggests that there are genetic factors involved in age-related macular degeneration. ${ }^{44,45}$ Results from population-based studies implicate a familial component in the disease's pathogenesis, ${ }^{46-49}$ as have studies of monozygotic ${ }^{50,51}$ and dizygotic ${ }^{52}$ twins. ${ }^{53}$ Klaver and colleagues ${ }^{47}$ have estimated that siblings of individuals with end-stage agerelated macular degeneration have about a five-fold increased risk for intermediate age-related macular degeneration and a twenty-fold increased risk for advanced age-related macular degeneration. They suggest that about $23 \%$ of advanced age-related macular degeneration can be attributed to a genetic component.

More recently, several studies have found an association between advanced age-related macular degeneration and complement factor $\mathrm{H}$, an integral component of the alternative pathway of complement activation. ${ }^{54-65}$ The gene for this compound is located on chromosome 1q32. The complement system may indeed have an important role in the pathogenesis of age-related macular degeneration, since other factors such as factor B and complement components $\mathrm{C} 2$ and $\mathrm{C} 3$ are also associated with age-related macular degeneration. 66,67 These observations suggest that age-related macular degeneration, like other age-related diseases such as Alzheimer's disease and atherosclerosis, might involve a major inflammatory component.

A second important locus LOC387715(ARMS2)/HtrA1 (high temperature requirement factor A-1), located on chromosome 10q26, has also been found to be associated with advanced agerelated macular degeneration. ${ }^{60,68-71}$ Both neovascular age-related macular degeneration and geographic atrophy have similar risk allele distribution. ${ }^{72}$ It is possible that variants of this protein and complement factor $\mathrm{H}$ contribute to the pathogenesis of age-related macular degeneration through their effect on precursors, such as drusen or changes in retinal pigment epithelial or Bruch's membranes. Both genetic variants seem to have independent effects on the progression of age-related macular degeneration. ${ }^{70} \mathrm{~A}$ few studies have assessed gene/gene interaction as well as gene/environment interaction. ${ }^{73-75}$ No definitive interaction has yet been found.

A number of other genes have been implicated in the pathogenesis of age-related macular degeneration, although their association has not been replicated in other studies or they account for only a small proportion of the disease. Understanding the dynamic interaction between genetic and environmental factors with cell biology and the pathology of the disease could be important in further understanding the pathophysiology of age-related macular degeneration.

The association of age-related macular degeneration with cardiovascular risk factors has also been investigated, with inconsistent results. Besides the consistent link between smoking and age-related macular degeneration, other factors such as hypertension, total serum cholesterol, HDL cholesterol, body-mass index, and the presence of cardiovascular disease do not seem to be associated with age-related macular degeneration in all studies. Using Medicare datawhich could be confounded by smoking — patients with age-related macular degeneration were shown to have an increased risk of myocardial infarction. ${ }^{76}$ These findings were not confirmed in other studies, although these studies included fewer individuals with advanced age-related macular degeneration. ${ }^{77-79}$

Increased concentrations of HDL cholesterol—considered to be cardioprotective-have been shown to be associated with a reduced risk of age-related macular degeneration. ${ }^{80,81}$ Another study found no association between late age-related macular degeneration and hypertension, a history of cardiovascular disease, or with serum lipid concentrations. ${ }^{82}$ Some studies have shown a direct association between age-related macular degeneration and raised concentration 
of cholesterol, both in the serum ${ }^{81}$ and in the diet. ${ }^{83}$ Some evidence exists for a link between risk for age-related macular degeneration and increased levels of total dietary fat ${ }^{84}$ although other studies have refuted this link. ${ }^{85}$ Specific types of fats might be differentially associated with the risk for age-related macular degeneration. ${ }^{86}$ Hypertension was found to be associated with age-related macular degeneration in some studies. ${ }^{87-89}$

Results from observational studies that assessed the effect of dietary antioxidants on risk for age-related macular degeneration have been inconsistent. ${ }^{90-95}$ In the Rotterdam Study, a high dietary intake of beta-carotene, vitamins $\mathrm{C}$ and $\mathrm{E}$, and zinc was associated with a substantially reduced risk of age-related macular degeneration in elderly individuals. ${ }^{96} \mathrm{~A}$ multicentre randomised trial has shown that oral supplements including high levels of antioxidants and minerals are effective in slowing the progression of advanced stages of age-related macular degeneration. ${ }^{2}$ By contrast, a trial of vitamin $\mathrm{E}$ in an Australian population with lower risk of developing advanced age-related macular degeneration failed to find a beneficial effect. ${ }^{97}$

Some case-control studies have found evidence of decreasing risk of neovascular age-related macular degeneration among individuals who reported the highest intake of dietary lutein and zeaxanthin, the major macular carotenoids ${ }^{98}$ that are found mostly in green leafy vegetables such as spinach, collard greens, and kale. ${ }^{90,91,99,100}$ However, another study found no such association. ${ }^{101}$ Population-based studies have shown in consistent associations of dietary levels of these compounds with age-related macular degeneration. ${ }^{94,96,102,103}$ Lutein and zeaxanthin might affect processes modulating light and oxidant exposure: ${ }^{104}$ both compounds reflect short-wavelength light, and reduced exposure to these wavelengths might reduce both photochemical and oxidant damage to cellular lipids, proteins, and nuclear material.

Docosahexanoic acid and eicosapentaenoic acid are part of the family of omega-3 long-chain polyunsaturated fatty acids that are found in high concentrations in the retinal tissue. Such fatty acids might affect factors and processes important in the angiogenesis cascade and in gene expression, and could be potent regulators of retinal cell survival, inflammation, and energy balance. The main sources of omega-3 fatty acids are fish products. Some case-control studies have found evidence of decreasing risk of neovascular age-related macular degeneration among individuals reporting the highest intake of omega- 3 fatty acids and fish, $, 05,106$ especially if in conjunction with lower levels of intake of linoleic acid. ${ }^{107}$ The Blue Mountains Eye Study showed that a reduction in incident early changes of age-related macular degeneration and the eating of fish three times per week could reduce the risk of advanced age-related macular degeneration. ${ }^{108}$

A number of other risk factors have been found. Blue iris colour has been inconsistently implicated as a risk factor for age-related macular degeneration and has been considered a possible marker for pigment content in the retinal pigment epithelium. ${ }^{109,110}$ There has also been considerable interest in whether sunlight exposure could be a risk factor for the development of age-related macular degeneration. The possibility that high levels of exposure to blue or visible light might cause ocular damage, especially in the development of age-related macular degeneration in the later years of life, has been suggested. ${ }^{111}$ The Pathologies Oculaires Liees a l'Age study reported that individuals who wore sunglasses regularly were less likely to develop soft drusen. ${ }^{112}$ Results from the Beaver Dam Study suggest that people who spent leisure time outdoors were at an increased risk of developing early age-related macular de generation. ${ }^{113}$ However, other epidemiological studies have shown little or no association between sunlight exposure and the risk of age-related macular degeneration. ${ }^{28,33}$, 114 


\section{Pathophysiology and pathology}

The pathology of age-related macular degeneration is characterised by degenerative changes involving the outer portion of the retina, retinal pigment epithelium, Bruch's membrane, and less prominently, the choriocapillaris. Late stage age-related macular degeneration shows the presence of neovascularisation, exudative change, or disciform scar in neovascular age-related macular degeneration. In atrophic age-related macular degeneration, there is retinal pigment epithelium loss or choriocapillaris attenuation without neo vascularisation. ${ }^{115}$ Early pathological changes in age-related macular degeneration involve basal deposits in Bruch's membrane. These deposits, which can only be shown on pathological specimens and not by clinical evaluation, are of two distinct types: ${ }^{116}$ basal laminar, composed of basement membrane protein and long-spacing collagen located between the retinal pigment epithelium plasma and basement membrane, and basal linear, which is more specific for early age-related macular degeneration and composed mainly of membraneous material located external to the basement membrane of the retinal pigment epithelium in Bruch's membrane. ${ }^{117}$ The combination of these deposits with secondary changes in the retinal pigment epithelium results in the formation of drusen (figure 4). Many different molecules have been identified in drusen, including glycoconjugates and a variety of components found in atherosclerotic plaques including vitronectin, apolipoprotein $\mathrm{B}$ and $\mathrm{E}$, alpha-crystallin, complement components, HtrA1, and lipids. ${ }^{11,118-121}$ Macrophages have been detected in regressing drusen, ${ }^{122}$ suggesting that macrophages are recruited to eliminate the age-accumulated deposits within Bruch's membrane (figure 5). Activated microglia also accumulate in age-related macular degeneration lesions. ${ }^{123}$ Discrete nodules or hard drusen deposits composed of a hyaline-like material are found between the retinal pigment epithelium and Bruch's membrane. Soft drusen are often large and are associated with the detachment of the retinal pigment epithelium and diffusely abnormal Bruch's membrane alterations. ${ }^{122,124}$ Soft drusen might be associated with further damage to the retina, retinal pigment epithelium, and choroid, thereby leading to choroidal neovascularisation or cell death in the retinal pigment epithelium and geographic atrophy.

On microscopy, geographic atrophy is seen as abnormal retinal pigment epithelium cells with hypotrophy, hypertrophy, hypopigmentation, hyperpigmentation, atrophy, migration, loss of outer retinal cells (particularly the photoreceptors), attenuation of Bruch's membrane, and choriocapillaris degeneration. ${ }^{115,125,126}$ Although the retinal pigment epithelium is the most affected cell type, the retinal outer nuclear layer is severely affected, with a 77\% reduction compared with age-matched control eyes. ${ }^{127}$ In the geographic atrophy associated with agerelated macular degeneration, atrophy of the retinal pigment epithelium is usually more severe than the loss of choriocapillaris. However, the surviving choriocapillaris in areas of complete loss of the retinal pigment epithelium seem to be highly constricted. ${ }^{126}$ Macrophages are often seen in areas of geographic atrophy and are apparently phagocytosing pigment and debris, as seen by electron microscopy or immunohistochemistry.

Emerging evidence indicates that the autofluorescent pigments that accumulate as lipofuscin in the cells of the retinal pigment epithelium might reach levels that contribute to a decline in cell function, retinal ageing, and degeneration, mainly in the form of geographic atrophy. ${ }^{128}$ Lipofuscin in the retinal pigment epithelium is the source of fundus autofluorescence. The compound is found as micrometre-sized spherical particles and is characterised by its yellow autofluorescence when exposed to blue light. ${ }^{129}$ The major component of lipofuscin is Nretinylidene-N-retinylethanol-amine (A2E), a quaternary amine and retinoid byproduct of the visual cycle. ${ }^{130}$ The generation of lipofuscin is a pathogenic cascade; the $\mathrm{A} 2 \mathrm{E}$ that is produced interferes with the function of cells in the retinal pigment epithelium, leading to apoptosis of the retinal pigment epithelium and subsequent geographic atrophy. Recently, fundus autofluorescence has been used to detect lipofuscin fluorophores in the retinal pigment 
epithelium. ${ }^{131}$ Specific patterns of fundus autofluorescence were associated with progression of geographic atrophy; this technique could be an important imaging method to monitor patients with geographic atrophy associated with age-related macular degeneration. ${ }^{132}$

Choroidal neovascularisation can occur in the macular, peripapillary, and peripheral regions. Early choroidal neovascularisation occurs under the retinal pigment epithelium, ${ }^{133,134}$ eventually breaking through ${ }^{135}$ to develop exudative, haemorrhagic, or disciform age-related macular degeneration (figure 6). In neovascular age-related macular degeneration, lipid-rich fluid accumulates under the retinal pigment epithelium or neuroretina. In haemorrhagic agerelated macular degeneration, blood breaks through the retinal pigment epithelium into the subretinal space and sometimes through the retina and into the vitreous. In disciform agerelated macular degeneration, fibrous tissue with neovascularisation and alteration of the retinal pigment epithelium proliferates and can partly or totally replace the neuroretina. The outer nuclear layer can be severely attenuated, with an almost $70 \%$ reduction of photoreceptor length shown in one study. ${ }^{136}$ Additional pathological findings include retinal pigment epithelium tear, serous exudation, haemorrhage, gliosis, and calcification. Macrophages have been documented both morphologically and functionally in neovascular age-related macular degeneration. ${ }^{137-142}$ Activated macrophages and microglia may secrete chemokines and cytokines, causing further cellular damage, Bruch's membrane degradation, and angiogenesis. 143

Complement factor $\mathrm{H}$, which downregulates the activity of the alternative complement pathway, is located in normal human retinal pigment epithelium, Bruch's membrane, and choroid. ${ }^{54} \mathrm{HtrA} 1$, a secretory protein and an inhibitor of transforming growth factor $\beta,{ }^{144}$ is also associated with the development of age-related macular degeneration. ${ }^{69,70,72,73}$ The rs11200638 allele of HtrA1 occurs at a higher frequency in patients with age-related macular degeneration than in those without the disease; the increased expression of HtrA1 - at both the mRNA and protein levels by reverse transcriptase PCR and immunohistochemistry-in agerelated macular degene ration lesions are consistent with a possible role of this protein in neovascular and atrophic age-related macular degeneration (figure 7). ${ }^{145}$ Recently, ARMS2 has been reported to be involved in mitochondrial homoeostasis. ${ }^{146}$

\section{Management}

\section{Prevention}

Since there is no cure for age-related macular degeneration, prevention is the first approach to reduce vision loss. Control of modifiable risk factors such as smoking, hypertension, and bodymass index could reduce the risk of developing age-related macular degeneration by half. ${ }^{147}$ Nutritional supplements can be used as a preventive therapy-the AREDS formulation of antioxidant multivitamins (vitamin C $500 \mathrm{mg}$, vitamin E $400 \mathrm{IU}$, beta-carotene $15 \mathrm{mg}$ ) and zinc (zinc oxide $80 \mathrm{mg}$ and cupric oxide $2 \mathrm{mg}$ ) has been shown to reduce the risk of developing advanced age-related macular degeneration and its associated visual loss by as much as $25 \%$ over 5 years in individuals with at least moderate risk of age-related macular degeneration. ${ }^{2}$ This was accompanied by a $19 \%$ reduction in the risk of moderate vision loss (three or more lines of vision loss on the visual acuity chart) at 5 years. However, this formulation is not recommended for smokers because beta-carotene has been shown to increase the risk of lung cancers. ${ }^{148,149}$

Recent analyses regarding potential harmful adverse effects of supplementation with high doses of vitamins have raised concerns. ${ }^{150}$ One meta-analysis found no increased risk of mortality overall, although subgroup analyses that excluded those studies that had no deaths found an increased risk of mortality. However, the methodology of this meta-analysis has been refuted by other investigators. ${ }^{151,152}$ Another concern was that large trials, especially those of 
beta-carotene in which heavy smokers were included, contributed substantially to the weight of the analyses, potentially biasing the final analyses towards a negative outcome. ${ }^{152,153}$ Another meta-analysis concluded that vitamin E in high doses (400 IU) was associated with an increased risk of mortality, ${ }^{154}$ while further analyses of three large clinical trials that used a dose of about 400 IU showed no statistical differences. ${ }^{155}$

The Age-Related Eye Disease Study 2 (AREDS2) is currently assessing the use of dietary supplements of lutein $(10 \mathrm{mg})$, zeaxanthin $(2 \mathrm{mg})$, and omega-3 fatty acids $(1 \mathrm{~g})$ for the prevention of advanced age-related macular degeneration. The study will also investigate whether the current AREDS formulation could be modified by reducing the amount of zinc or eliminating the beta-carotene. The level of zinc in the current formulation is considered high and there is evidence that only $25 \mathrm{mg}$ can be absorbed by the body per day. Beta-carotene, which is not present within the eye, is a problem for smokers.

\section{Laser treatment}

The Complications of Age-Related Macular Degeneration Prevention Trial, a controlled clinical trial that assessed the role of laser photocoagulation for the treatment of individuals with large drusen, showed that although drusen disappeared with treatment, there was no reduction in the risk for the development of advanced age-related macular degeneration. ${ }^{156}$ At 5 years, about $20 \%$ of both the treated and untreated group experienced vision loss; $15 \%$ in each group developed neovascular age-related macular degeneration and about $7 \%$ developed geographic atrophy. Laser treatment did seem to delay the development of choroidal neovascularisation by 6 months in studies that included patients with unilateral advanced agerelated macular degeneration. ${ }^{157,158}$

\section{Laser photocoagulation}

For patients who have already developed neovascular age-related macular degeneration, early detection-before significant visual loss develops-is associated with a better prognosis. In the 1980s, the Macular Photo-coagulation Study ${ }^{159,160}$ showed a reduction in vision loss associated with thermal laser photocoagulation, provided the neovascular lesion had welldemarcated (classic) boundaries. However, such lesions are present in no more than 15-20\% of patients with neovascular age-related macular degeneration. Furthermore, thermal laser photocoagulation can cause visual loss because of laser-induced retinal damage, and is associated with high recurrence rates, usually along the foveal side of the lesion, that often lead to eventual vision loss.

\section{Photodynamic therapy}

In 2000, photodynamic therapy with verteporfin was approved as an alternative treatment for patients with neovascular age-related macular degeneration. Two large randomised controlled trials ${ }^{161,162}$ showed a significant reduction in moderate vision loss in patients with predominantly classic choroidal neovascularisation. Vision was stabilised in $61 \%$ of patients treated with verteporfin, compared with $46 \%$ of patients given placebo. One of the studies ${ }^{163}$ showed a benefit for patients with minimally classic disease provided that their lesions were small (four disc areas or less) or their baseline visual acuity was reduced (Snellen equivalent of 20/50 or worse). The dose of verteporfin is determined by body surface area ( 6 $\mathrm{mg} / \mathrm{m}^{2}$ ) and the drug is given intravenously over $10 \mathrm{~min}$. After a 5-minute accumulation phase, the drug is activated with low-energy laser light for $83 \mathrm{~s}$ using the peak absorbance wavelength for the drug $(689 \mathrm{~nm})$. This induces temporary closure of the choroidal neovascular complex while sparing the overlying retinal structures. Because the retina is largely spared, this treatment has, for the most part, replaced photocoagulation as the standard treatment for choroidal neovascularisation, even though the average patient requires a number of treatments over a 2-year period. Adverse effects are rare, but individuals are advised to avoid direct 
sunlight or bright illumination for 5 days to prevent phototoxicity. Overdose of the drug or light can result in non-perfusion of the retinal vasculature, with subsequent severe visual loss due to macular infarction. About 3-4\% of treated patients experience severe vision loss in the normal administration of this drug, although some of this loss is reversible. ${ }^{162}$

\section{Vascular endothelial growth factor (VEGF) inhibitors}

In December, 2004, the US Food and Drug Administration (FDA) approved pegaptanib, the first anti-angiogenic drug for the eye. This drug targets vascular endothelial growth factor (VEGF), a protein that acts as one of the signals that triggers angiogenesis and increased permeability. Findings from two phase III randomised trials of pegaptanib, involving about 1200 patients with all subtypes of neovascular age-related macular degeneration, showed a significant benefit over 2 years. Vision was stabilised in $70 \%$ of patients treated with pegaptanib compared with $55 \%$ of patients receiving placebo. ${ }^{163}$ During the 48 weeks of the trials, pegaptanib was administered intravitreally every 6 weeks at a dose of $0.3 \mathrm{mg}$. Among the adverse events that occurred, the most serious were endophthalmitis (1.3\%), traumatic injury to the lens $(0.7 \%)$, and retinal detachment $(0.6 \%)$, leading to severe visual loss in $0.1 \%$ of patients.

In June, 2006, the FDA approved another VEGF inhibitor-ranibizumab—for the treatment of neo-vascular age-related macular degeneration. Ranibizumab is a fragment of a monoclonal antibody that binds to and inhibits all forms of VEGF-A. ${ }^{164,165}$ This drug, when injected intravitreally on a monthly basis, prevented vision loss and, for the first time with any treatment for age-related macular degeneration, was associated with a remarkable proportion of patients with an improvement in vision. At 12 months, $95 \%$ of patients given ranibizumab $0.5 \mathrm{mg}$ lost fewer than 15 letters (three lines of vision) compared with $62 \%$ of the placebo group $(\mathrm{p}<0.001)$. Additionally, $34 \%$ of this group improved by 15 or more letters of vision compared with the $5 \%$ in the placebo group ( $\mathrm{p}<0 \cdot 001)$. These benefits persisted through 24 months of follow-up. Mean differences in visual acuity score in the treated and control groups were also impressive, with a mean increase of seven letters in the treated group compared with a mean decrease of 10 letters in the placebo group ( $<<0 \cdot 001)$. The adverse effects included endophthalmitis (1\%) and serious uveitis (1\%).

Before the FDA approval of this drug, some ophthalmologists had begun to use a closely related monoclonal antibody, bevacizumab, to treat neovascular age-related macular degeneration, with impressive results. ${ }^{166}$ Because ranibizumab had not yet been approved by the FDA, and since bevacizumab was licensed for use in colon cancer, the off-label use of the latter drug spread worldwide. At present, there are no data to compare the two drugs directly, although a randomised comparison has begun. This study will also assess the potential effects of reduced treatment frequency to alleviate the treatment burden of monthly intravitreal injections. There is also a need to gather further information of a potential increase in risk of strokes with these anti-VEGF agents.

\section{Other therapies}

The quest for treatment for this blinding condition continues, since only a portion of treated patients experience an improvement in visual acuity. A number of other therapies have been tried, including surgery, radiation, and other pharmacological agents. It is possible that like cancer therapies, combination treatments could improve both visual gain and durability of therapies in individuals affected by age-related macular degeneration. With better understanding of the inflammatory pathways that may be implicated in the pathogenesis of this disease, and an increased knowledge of the interactions between genetics and the environment (environmental epigenomics and disease susceptibility), we may find improved therapies for age-related macular degeneration. 


\section{Acknowledgments}

We thank Pamela Sieving for her assistance in the literature search for this paper.

\section{References}

1. The Eye Diseases Prevalence Research Group. Causes and prevalence of visual impairment among adults in the United States. Arch Ophthalmol 2004;122:477-485. [PubMed: 15078664]

2. The Age-Related Eye Disease Study Research Group. A randomized, placebo-controlled, clinical trial of high-dose supplementation with vitamins $\mathrm{C}$ and $\mathrm{E}$, beta carotene, and zinc for age-related macular degeneration and vision loss. Arch Ophthalmol 2001;119:1417-1436. [PubMed: 11594942]

3. Bird AC, Bressler NM, Bressler SB, et al. The International ARM Epidemiological Study Group. An international classification and grading system for age-related maculopathy and age-related macular degeneration. Surv Ophthalmol 1995;39:367-374. [PubMed: 7604360]

4. Vingerling JR, Dielemans I, Hofman A, et al. The prevalence of age-related maculopathy in the Rotterdam Study. Ophthalmology 1995;102:205-210. [PubMed: 7862408]

5. Munoz B, West SK, Rubin GS, et al. Causes of blindness and visual impairment in a population of older Americans: the Salisbury Eye Evaluation Study. Arch Ophthalmol 2000;118:819-825. [PubMed: 10865321]

6. Weih LM, VanNewkirk MR, McCarty CA, Taylor HR. Age-specific causes of bilateral visual impairment. Arch Ophthalmol 2000;118:264-269. [PubMed: 10676793]

7. Age-Related Eye Disease Study Research Group. The Age-Related Eye Disease Study severity scale for age-related macular degeneration. Arch Ophthalmol 2005;123:1484-1498. [PubMed: 16286610]

8. Age-Related Eye Disease Study Research Group. A simplified severity scale for age-related macular degeneration. Arch Ophthalmol 2005;123:1570-1574. [PubMed: 16286620]

9. de Jong PT. Age-related macular degeneration. N Engl J Med 2006;355:1474-1485. [PubMed: 17021323]

10. Ambati J, Ambati BK, Yoo SH, Ianchulev S, Adamis AP. Age-related macular degeneration: etiology, pathogenesis, and therapeutic strategies. Surv Ophthalmol 2003;48:257-293. [PubMed: 12745003]

11. Zarbin MA. Current concepts in the pathogenesis of age-related macular degeneration. Arch Ophthalmol 2004;122:598-614. [PubMed: 15078679]

12. Holz FG, Pauleikhoff D, Klein R, Bird AC. Pathogenesis of lesions in late age-related macular disease. Am J Ophthalmol 2004;137:504-510. [PubMed: 15013875]

13. Nussenblatt RB, Ferris FL. Age-related macular degeneration and the immune response: implications for therapy. Am J Ophthalmol 2007;144:618-626. [PubMed: 17698021]

14. Age-Related Eye Disease Study Research Group. Potential public health impact of Age-Related Eye Disease Study results. Arch Ophthalmol 2003;121:1621-1624. [PubMed: 14609922]

15. Bunce C, Wormald R. Causes of blind certifications in England and Wales: April 1999-March 2000. Eye 2008;22:905-911. [PubMed: 17332762]

16. Smith W, Assink J, Klein R, et al. Risk factors for age-related macular degeneration: pooled findings from three continents. Ophthalmology 2001;108:697-704. [PubMed: 11297486]

17. Mitchell P, Wang JJ, Foran S, Smith W. Five-year incidence of age-related maculopathy lesions: the Blue Mountains Eye Study. Ophthalmology 2002;109:1092-1097. [PubMed: 12045049]

18. Wang JJ, Foran S, Mitchell P. Age-specific prevalence and causes of bilateral and unilateral visual impairment in older Australians: the Blue Mountains Eye Study. Clin Experiment Ophthalmol 2000;28:268-273. [PubMed: 11021555]

19. Klein R, Klein BE, Knudtson MD, Meuer SM, Swift M, Gangnon RE. Fifteen-year cumulative indicence of age-related macular degeneration. Ophthalmology 2007;114:253-262. [PubMed: 17270675]

20. van Leeuwen R, Klaver CC, Vingerling JR, Hofman A, de Jong PT. The risk and natural course of age-related maculopathy: follow-up at 61/2 years in the Rotterdam Study. Arch Ophthalmol 2003;121:519-526. [PubMed: 12695249]

21. Mukesh BN, Dimitrov PN, Leikin S, et al. Five year incidence of age-related maculopathy: Visual Impairment Project. Ophthalmology 2004;111:1176-1182. [PubMed: 15177968] 
22. Mitchell P, Smith W, Attebo K, et al. Prevalence of age-related maculopathy in Australia. Ophthalmology 1995;102:1450-1460. [PubMed: 9097791]

23. Klein R, Klein BE, Linton KL. Prevalence of age-related maculopathy. Ophthalmology 1992;99:933943. [PubMed: 1630784]

24. Cruickshanks KJ, Hamman RF, Klein R, et al. The prevalence of age-related maculopathy by geographic region and ethnicity. Arch Ophthalmol 1997;115:242-250. [PubMed: 9046260]

25. Friedman DS, Katz J, Bressler NM, et al. Racial differences in the prevalence of age-related macular degeneration: the Baltimore Eye Survey. Ophthalmology 1999;106:1049-1055. [PubMed: 10366070]

26. Bressler NM, Bressler SB, West SK, et al. The grading and prevalence of macular degeneration in Chesapeake Bay waterman. Arch Ophthalmol 1989;107:847-852. [PubMed: 2786408]

27. VanNewkirk MR, Nanjan MB, Wanh JJ, et al. The prevalence of age-related maculopathy: the visual impairment project. Ophthalmology 2000;107:1593-1600. [PubMed: 10919916]

28. The Age-Related Eye Disease Study Research Group. Risk factors associated with age-related macular degeneration: a case-control study in the Age-Related Eye Disease Study. Ophthalmology 2000;107:2224-2232. [PubMed: 11097601]

29. Delcourt C, Diaz JL, Ponton-Sanchez A, Papoz L. Smoking and age-related macular degeneration. Arch Ophthalmol 1998;116:1031-1035. [PubMed: 9715683]

30. Hyman LG, Lilienfeld AM, Ferris FL III, et al. Senile macular degeneration: a case-control study. Am J Epidemiol 1983;118:213-227. [PubMed: 6881127]

31. Vinding T, Appleyard M, Nyboe J, et al. Risk factor analysis for atrophic and exudative age-related macular degeneration. An epidemiologic study of 1000 aged individuals. Acta Ophthalmol 1992;70:215-222.

32. McCarty CA, Mukesh BN, Fu CL, et al. Risk factors for age-related maculopathy: the Visual Impairment Project. Arch Ophthalmol 2001;119:1455-1462. [PubMed: 11594944]

33. The Eye Disease Case-Control Study Group. Risk factors for neovascular age-related macular degeneration. Arch Ophthalmol 1992;110:1701-1708. [PubMed: 1281403]

34. Vingerling JR, Hofman A, Grobbee DE, et al. Age-related macular degeneration and smoking. Arch Ophthalmol 1996;114:1193-1196. [PubMed: 8859077]

35. Klein R, Klein BEK, Linton KL, et al. The Beaver Dam Eye Study: the relation of age-related maculopathy to smoking. Am J Epidemiol 1993;137:190-200. [PubMed: 8452123]

36. Smith W, Mitchell P, Leeder SR. Smoking and age-related maculopathy. Arch Ophthalmol 1996;114:1518-1523. [PubMed: 8953988]

37. Seddon JM, Willett WC, Speizer FE, et al. A prospective study of cigarette smoking and age-related macular degeneration in women. JAMA 1996;276:1141-1146. [PubMed: 8827966]

38. Christen WG, Glynn RJ, Manson FE, et al. A prospective study of cigarette smoking and risk of agerelated macular degeneration in men. JAMA 1996;276:1147-1151. [PubMed: 8827967]

39. Khan JC, Thurlby DA, Shahid H, et al. Smoking and age-related macular degeneration: the number of pack years of cigarette smoking is a major determinant of risk for both geographic atrophy and choroidal neovascularization. Br J Ophthalmol 2006;90:75-80. [PubMed: 16361672]

40. Chaine G, Hullo A, Sahel J, et al. Case-control study of the risk factors for age related macular degeneration. Br J Ophthalmol 1998;276:996-1002. [PubMed: 9893587]

41. Klein R, Klein BE, Jenson SC, et al. Age-related maculopathy in a multiracial United States population: the National Health and Nutrition Examination Survey III. Ophthalmology 1999;106:1056-1065. [PubMed: 10366071]

42. Schachat AP, Hyman L, Leske MC, et al. Features of age-related macular degeneration in a black population. Arch Ophthalmol 1995;113:728-735. [PubMed: 7786213]

43. Klein R, Klein BE, Knudtson MD, et al. Prevalence of age-related macular degeneration in 4 racial/ ethnic groups in the multi-ethnic study of atherosclerosis. Ophthalmology 2006;113:373-380. [PubMed: 16513455]

44. Haddad S, Chen CA, Santangelo SL, Seddon JM. The genetics of age-related macular degeneration: a review of progress to date. Surv Ophthalmol 2006;51:316-363. [PubMed: 16818082] 
45. Scholl HPN, Fleckenstein M, Issa PC, Keilhauer C, Holz FG, Weber BH. An update on the genetics of age-related macular degeneration. Mol Vis 2007;13:196-205. [PubMed: 17327825]

46. Heiba IM, Elston RC, Klein BE, Klein R. Sibling correlations and segregation analysis of age-related maculopathy: the Beaver Dam Eye Study. Genet Epidemiol 1994;11:51-67. [PubMed: 8013888]

47. Klaver CC, Wolfs RC, Assink JJ, et al. Genetic risk of age-related maculopathy. Population-based familial aggregation study. Arch Ophthalmol 1998;116:1646-1651. [PubMed: 9869796]

48. Seddon JM, Ajani UA, Mitchell BD. Familial aggregation of age-related maculopathy. Am J Ophthalmol 1997;123:199-206. [PubMed: 9186125]

49. Smith W, Mitchell P. Family history and age-related maculopathy: the Blue Mountains Eye Study. Aust N Z J Ophthalmol 1998;26:203-206. [PubMed: 9717749]

50. Gottfredsdottir MS, Sverrisson T, Musch DC, et al. Age related macular degeneration in monozygotic twins and their spouses in Iceland. Acta Ophthalmol Scand 1999;77:422-425. [PubMed: 10463414]

51. Klein ML, Maudlin WM, Stoumbos VD. Heredity and age-related macular degeneration. Observations in monozygotic twins. Arch Ophthalmol 1994;112:932-937. [PubMed: 8031273]

52. Meyers SM, Greene T, Gutman FA. A twin study of age-related macular degeneration. Am J Ophthalmol 1995;120:757-766. [PubMed: 8540549]

53. Seddon JM, Cote J, Page WF, Aggen SH, Neale MC. The US twin study of age-related macular degeneration: relative roles of genetic and environmental influences. Arch Ophthalmol 2005;123:321-327. [PubMed: 15767473]

54. Klein RJ, Zeiss C, Chew EY, et al. Complement factor H polymorphism in age-related macular degeneration. Science 2005;308:385-389. [PubMed: 15761122]

55. Edwards AO, Ritter R III, Abel KJ, Manning A, Panhuysen C, Farrer LA. Complement factor H polymorphism and age-related macular degeneration. Science 2005;308:421-424. [PubMed: 15761121]

56. Haines JL, Hauser MA, Schmidt S, et al. Complement factor H variant increases the risk of agerelated macular degeneration. Science 2005;308:419-421. [PubMed: 15761120]

57. Hageman GS, Anderson DH, Johnson LV, et al. A common haplotype in the complement regulatory gene factor $\mathrm{H}(\mathrm{HF} 1 / \mathrm{CFH})$ predisposes individuals to age-related macular degeneration. Proc Natl Acad Sci USA 2005;102:7227-7232. [PubMed: 15870199]

58. Conley YP, Thalamuthu A, Jakobsdottir J, et al. Candidate gene analysis suggests a role for fatty acid biosynthesis and regulation of the complement system in the etiology of age-related maculopathy. Hum Mol Genet 2005;14:1991-2002. [PubMed: 15930014]

59. Zareparsi S, Branham KE, Li M, et al. Strong association of the Y402H variant in complement factor $\mathrm{H}$ at 1q32 with susceptibility to age-related macular degeneration. Am J Hum Genet 2005;77:149153. [PubMed: 15895326]

60. Rivera A, Fisher SA, Fritsche LG, et al. Hypothetical LOC387715 is a second major susceptibility gene for age-related macular degeneration contributing independently of complement factor $\mathrm{H}$ to disease risk. Hum Mol Genet 2005;14:3227-3236. [PubMed: 16174643]

61. Souied EH, Leveziel N, Richard F, et al. Y402H complement factor H polymorphism associated with exudative age-related macular degeneration in the French population. Mol Vis 2005;11:1135-1140. [PubMed: 16379025]

62. Sepp T, Khan JC, Thurlby DA, et al. Complement factor H variant Y402H is a major risk determinant for geographic atrophy and choroidal neovascularization in smokers and nonsmokersComplement factor $\mathrm{H}$ variant $\mathrm{Y} 402 \mathrm{H}$ is a major risk determinant for geographic atrophy and choroidal neovascularization in smokers and nonsmokers. Invest Ophthalmol Vis Sci 2006;47:536-540. [PubMed: 16431947]

63. Magnusson KP, Duan S, Sigurdsson H, et al. CFH Y402H confers similar risk of soft drusen and both forms of advanced AMD. PLoS Med 2005;3:e5. [PubMed: 16300415]

64. Lau LI, Chen SJ, Cheng CY, et al. Association of the Y402H polymorphism in complement factor $\mathrm{H}$ gene and neovascular age-related macular degeneration in Chinese patients. Invest Ophthalmol Vis Sci 2006;47:3242-3246. [PubMed: 16877387]

65. Okamoto H, Umeda S, Obazawa M, et al. Complement factor H polymorphisms in Japanese population with age-related macular degeneration. Mol Vis 2006;12:156-158. [PubMed: 16541016] 
66. Gold B, Merriam JE, Zernant J, et al. Variation in factor B (BF) and complement component 2 (C2) genes is associated with age-related macular degeneration. Nat Genet 2006;38:458-462. [PubMed: 16518403]

67. Yates YR, Sepp T, Matharu BK, et al. Complement C3 variant and the risk of age-related macular degeneration. N Engl J Med 2007;357:19-27.

68. Jakobsdottir J, Conley YP, Weeks DE, Mah TS, Ferrell RE, Gorin MB. Susceptibility genes for agerelated maculopathy on chromosome 10q26. Am J Hum Genet 2005;77:389-407. [PubMed: 16080115]

69. Dewan A, Liu M, Hartman S, et al. HTRA1 promoter polymorphism in wet age-related macular degeneration. Science 2006;314:989-992. [PubMed: 17053108]

70. Seddon JM, Francis PJ, George S, Schultz DW, Rosner B, Klein MI. Association of CFH Y402H and LOC387715 A69S with progression of age-related macular degeneration. JAMA 2007;297:17931800. [PubMed: 17456821]

71. Ross RJ, Bojanowski CM, Wang JJ, et al. The LOC387715 polymorphism and age-related macular degeneration replication in 3 case-control samples. Invest Ophthalmol Vis Sci 2007;48:1128-1132. [PubMed: 17325155]

72. Yang Z, Camp NJ, Sun H, et al. A variant of the HTRA1 gene increases susceptibility to age-related macular degeneration. Science 2006;314:992-993. [PubMed: 17053109]

73. Francis PJ, George S, Schultz DW, et al. The LOC387715 gene, smoking, body mass index, environmental associations with advanced age-related macular degeneration. Hum Hered 2007;63:212-218. [PubMed: 17347568]

74. Schmidt S, Hauser MA, Scott WK, et al. Cigarette smoking strongly modifies the association of LOC387715 and age-related macular degeneration. Am J Hum Genet 2006;78:852-864. [PubMed: 16642439]

75. Seddon JM, George S, Rosner B, Klein ML. CFH gene variant, Y402H, and smoking, body mass index, environmental associations with advanced age-related macular degeneration. Hum Hered 2006;61:157-165. [PubMed: 16816528]

76. Duan Y, Mo J, Klein R, et al. Age-related macular degeneration is associated with incident myocardial infarction among elderly Americans. Ophthalmology 2007;114:732-737. [PubMed: 17187863]

77. Wong TY, Tikellis, Sun C, Klein R, Douper DJ, Sharrett AR. Age-related macular degeneration and risk of coronary heart disease: the Atherosclerosis Risk in Communities Study. Ophthalmology 2007;114:86-91. [PubMed: 17198851]

78. Tan JS, Mitchell P, Smith W, Wang JJ. Cardiovascular risk factors and the long-term incidence of age-related macular degeneration. Ophthalmology 2007;125:1089-1095.

79. Klein R, Deng Y, Klein BE, et al. Cardiovascular disease, its risk factors and treatment and age-related macular degeneration: Women's Health Initiative Sight Exam ancillary Study. Am J Ophthalmol 2007;143:473-483. [PubMed: 17317391]

80. Hyman L, Schachat AP, He Q, Leske MC. Hypertension, cardiovascular disease, and age-related macular degeneration. Arch Ophthalmol 2000;118:351-358. [PubMed: 10721957]

81. Tomany SC, Wang JJ, van Leeuwen R, et al. Risk factors for incident age-related macular degeneration. Pooled findings from 3 continents. Ophthalmology 2004;111:1280-1287. [PubMed: 15234127]

82. Delcourt C, Michel F, Colvez A, et al. Associations of cardiovascular disease and its risk factors with age-related macular degeneration: the POLA study. Ophthalmic Epidemiol 2001;8:237-249. [PubMed: 11471092]

83. Mares-Perlman JA, Brady WE, Klein R, et al. Dietary fat and age-related maculopathy. Arch Ophthalmol 1995;113:743-748. [PubMed: 7786215]

84. Cho E, Hung S, Willett C, et al. Prospective study of dietary fat and the risk of age-related macular degeneration. Am J Clin Nutr 2001;73:209-218. [PubMed: 11157315]

85. Heuberger RA, Mares-Perlman JA, Klein R, et al. Relationship of dietary fat to age-related maculopathy in the Third National Health and Nutrition Examination Survey. Arch Ophthalmol 2001;119:1833-1838. [PubMed: 11735796]

86. Seddon JM, Rosner B, Sperduto RD, et al. Dietary fat and risk for advanced age-related macular degeneration. Arch Ophthalmol 2001;119:1191-1199. [PubMed: 11483088] 
87. Klein R, Klein BE, Tomany SC, Cruickshanks KJ. The association of cardiovascular disease with the long-term incidence of age-related maculopathy. Ophthalmology 2003;110:1273-1280. [PubMed: 12799274]

88. Fraser-Bell S, Wu J, Klein R, et al. Cardiovascular risk factors and age-related macular degeneration: the Los Angeles Latino Eye Study. Am J Ophthalmol 2008;145:308-316. [PubMed: 18222193]

89. Hogg RE, Woodside JV, Gilchrist SE, et al. Cardiovascular disease and hypertension are strong risk factors for choroidal neovascularization. Ophthalmology 2008;115:1046-1052. [PubMed: 17953990]

90. Seddon JM, Ajani UA, Sperduto RD, et al. Dietary carotenoids, vitamins A, C, and E, and advanced age-related macular degeneration. JAMA 1994;272:1413-1420. [PubMed: 7933422]

91. Snellen EL, Verbeek AL, Van Den Hoogen GW, Cruysberg JR, Hoyng CB. Neovascular age-related macular degeneration and its relationship to antioxidant intake. Acta Ophthalmol Scand 2002;80:368-371. [PubMed: 12190777]

92. Goldberg J, Flowerdew G, Smith E, Brody JA, Tso MO. Factors associated with age-related macular degeneration: an analysis of data from the first National Health and Nutrition Examination Survey. Am J Epidemiol 1988;128:700-710. [PubMed: 3421236]

93. Van den Langenberg GM, Mares-Perlman JA, Klein R, Klein BE, Brady WE, Palta M. Associations between antioxidant and zinc intake and the 5-year incidence of early age-related maculopathy in the Beaver Dam Eye Study. Am J Epidemiol 1998;148:204-214. [PubMed: 9676703]

94. Flood V, Smith W, Wang JJ, Manzi F, Webb K, Mitchell P. Dietary antioxidant intake and incidence of early age-related maculopathy: the Blue Mountains Eye Study. Ophthalmology 2002;109:22722278. [PubMed: 12466170]

95. Vu HTV, Robman L, McCarty CA, Taylor HR, Hodge A. Does dietary lutein and zeaxanthin increase the risk of age-related macular degeneration? Br Jr Ophthalmol 2006;90:389-390.

96. Van Leeuwen R, Boekhoom S, Vingerling JR, et al. Dietary intake of antioxidants and risk of agerelated macular degeneration. JAMA 2005;294:3101-3107. [PubMed: 16380590]

97. Taylor HR, Tikellis G, Robman LD, McCarty CA, McNeil JJ. Vitamin E supplementation and macular degeneration: randomized controlled trial. BMJ 2002;325:11. [PubMed: 12098721]

98. Landrum JT, Bone RA. Lutein, zeaxanthin, and the macular pigment. Arch Biochem Biophys 2001;385:28-40. [PubMed: 11361022]

99. Eye Disease Case-Control Study Group. Antioxidant status and neovascular age-related macular degeneration. Arch Ophthalmol 1993;111:104-109. [PubMed: 7678730]

100. SanGiovanni, JP.; Chew, EY.; Clemons, TE., et al. The relationship of dietary carotenoid and vitamin $\mathrm{A}, \mathrm{E}$, and $\mathrm{C}$ intake with age-related macular degeneration in a case-control study. AREDS Report No. 22; Arch Ophthalmol. 2007. p. 1225-1232.

101. Cho E, Seddon JM, Rosner B, Willett WC, Hankinson SE. Prospective study of intake of fruits, vegetables, vitamins, and carotenoids and risk of age-related maculopathy. Arch Ophthalmol 2004;122:883-892. [PubMed: 15197064]

102. Mares-Perlman JA, Fisher AI, Klein R, et al. Lutein and zeaxanthin in the diet and serum and their relation to age-related maculopathy in the third national health and nutrition examination survey. Am J Epidemiol 2001;153:424-432. [PubMed: 11226974]

103. Mares-Perlman JA, Klein R, Klein BE, et al. Association of zinc and antioxidant nutrients with agerelated maculopathy. Arch Ophthalmol 1996;114:991-997. [PubMed: 8694736]

104. Krinsky NI, Landrum JT, Bone RA. Biologic mechanisms of the protective role of lutein and zeaxanthin in the eye. Annu Rev Nutr 2003;23:171-201. [PubMed: 12626691]

105. SanGiovanni JP, Chew EY, Clemons TE, et al. The relationship of dietary lipid intake and agerelated macular degeneration in a case-control study. Arch Ophthalmol 2007;125:671-679. [PubMed: 17502507]

106. Seddon JM, Rosner B, Sperduto RD, et al. Dietary fat and risk for advanced age-related macular degeneration. Arch Ophthalmol 2001;119:1191-1199. [PubMed: 11483088]

107. Seddon JM, Cote J, Rosner B. Progression of age-related macular degeneration: association with dietary fat, transunsaturated fat, nuts, and fish intake. Arch Ophthalmol 2003;121:1728-1737. [PubMed: 14662593] 
108. Chua B, Flood V, Rochtchina E, Wang JJ, Smith W, Mitchell P. Dietary fatty acids and the 5-year incidence of age-related maculopathy. Arch Ophthalmol 2006;124:981-986. [PubMed: 16832021]

109. Hyman LG, Lilienfeld AM, Ferris FL III, et al. Senile macular degeneration: a case-control study. Am J Epidemiol 1983;118:213-227. [PubMed: 6881127]

110. Klein R, Klein BE, Jensen SC, Cruickshanks KJ. The relationship of ocular factors to the incidence and progression of age-related maculopathy. Arch Ophthalmol 1998;116:506-513. [PubMed: 9565051]

111. Taylor HR, West S, Munoz B, Rosenthal FS, Bressler SB, Bressler NM. The long-term effectsof visible light on the eye. Arch Ophtahlmol 1992;110:99-104.

112. Delcourt C, Carriere I, Ponton-Sanchez A, et al. Light exposure and the risk of age-related macular degeneration: the POLA Study. Arch Ophthalmol 2001;119:1463-1468. [PubMed: 11594945]

113. Klein R, Klein BE, Jensen SC, Cruickshanks KJ. Sunlight and the 5-year incidence of early agerelated maculopathy: the Beaver Dam Eye Study. Arch Ophthalmol 2001;119:246-250. [PubMed: 11176987]

114. Klein, R. Epidemiology. In: Berger, JW.; Fine, SL.; Maguire, MG., editors. Age-related macular degeneration. St Louis: Mosby, Inc; 1999. p. 31-55.

115. Green WR, Enger C. Age-related macular degeneration histopathologic studies. The 1992 Lorenz E Zimmerman Lecture. Ophthalmology 1993;100:1519-1535. [PubMed: 7692366]

116. Green WR. Histopathology of age-related macular degeneration. Mol Vis 1999;5:27. [PubMed: 10562651]

117. Sarks S, Cherepanoff S, Killingsworth M, Sarks J. Relationship of basal laminar deposit and membranous debris to the clinical presentation of early age-related macular degeneration. Invest Ophthalmol Vis Sci 2007;48:968-977. [PubMed: 17325134]

118. Mullins RF, Russell SR, Anderson DH, Hageman GS. Drusen associated with aging and age-related macular degeneration contain proteins common to extracellular deposits associated with atherosclerosis, elastosis, amyloidosis, and dense deposit disease. Faseb J 2000;14:835-846. [PubMed: 10783137]

119. Mullins RF, Johnson LV, Anderson DH, Hageman GS. Characterization of drusen-associated glycoconjugates. Ophthalmology 1997;104:288-294. [PubMed: 9052634]

120. Hageman GS, Mullins RF, Russell SR, Johnson LV, Anderson DH. Vitronectin is a constituent of ocular drusen and the vitronectin gene is expressed in human retinal pigmented epithelial cells. Faseb J 1999;13:477-484. [PubMed: 10064614]

121. Anderson DH, Ozaki S, Nealon M, et al. Local cellular sources of apolipoprotein E in the human retina and retinal pigmented epithelium: implications for the process of drusen formation. Am J Ophthalmol 2001;131:767-781. [PubMed: 11384575]

122. Sarks SH, Arnold JJ, Killingsworth MC, Sarks JP. Early drusen formation in the normal and aging eye and their relation to age related maculopathy: a clinicopathological study. Br J Ophthalmol 1999;83:358-368. [PubMed: 10365048]

123. Gupta N, Brown KE, Milam AH. Activated microglia in human retinitis pigmentosa, late-onset retinal degeneration, and age-related macular degeneration. Exp Eye Res 2003;76:463-467. [PubMed: 12634111]

124. Bressler NM, Silva JC, Bressler SB, Fine SL, Green WR. Clinicopathologic correlation of drusen and retinal pigment epithelial abnormalities in age-related macular degeneration. Retina 1994;14:130-142. [PubMed: 8036323]

125. Lutty G, Grunwald J, Majji AB, Uyama M, Yoneya S. Changes in choriocapillaris and retinal pigment epithelium in age-related macular degeneration. Mol Vis 1999;5:35. [PubMed: 10562659]

126. McLeod DS, Taomoto M, Otsuji T, Green WR, Sunness JS, Lutty GA. Quantifying changes in RPE and choroidal vasculature in eyes with age-related macular degeneration. Invest Ophthalmol Vis Sci 2002;43:1986-1993. [PubMed: 12037009]

127. Kim SY, Sadda S, Humayun MS, de Juan E Jr, Melia BM, Green WR. Morphometric analysis of the macula in eyes with geographic atrophy due to age-related macular degeneration. Retina 2002;22:464-470. [PubMed: 12172114]

128. Sparrow JR, Boulton M. RPE lipofuscin and its role in retinal pathobiology. Exp Eye Res 2005;80:595-606. [PubMed: 15862166] 
129. Lamb LE, Simon JD. A2E: a component of ocular lipofuscin. Photochem Photobiol 2004;79:127136. [PubMed: 15068025]

130. Sparrow JR, Fishkin N, Zhou J, et al. A2E, a byproduct of the visual cycle. Vision Res 2003;43:29832990. [PubMed: 14611934]

131. Schmitz-Valckenberg S, Bindewald-Wittich A, Dolar-Szczasny J, et al. Fundus autofluorescence in age-related macular degermation study group. Invest Ophthalmol Vis Sci 2006;47:2648-2654. [PubMed: 16723482]

132. Holz FG, Bindewald-Wittich A, Fleckenstein M, et al. FAM Study Group. Progression of geographic atrophy and impact of fundus autofluorescence patterns in age-related macular degeneration. Am J Ophthalmol 2007;143:463-472. [PubMed: 17239336]

133. Sarks JP, Sarks SH, Killingsworth MC. Morphology of early choroidal neovascularisation in agerelated macular degeneration: correlation with activity. Eye 1997;11:515-522. [PubMed: 9425418]

134. Gass JD. Choroidal neovascular membranes - their visualization and treatment. Trans Am Acad Ophthalmol Otolaryngol 1973;77:OP310-OP320. [PubMed: 4731492]

135. Grossniklaus HE, Green WR. Choroidal neovascularization. Am J Ophthalmol 2004;137:496-503. [PubMed: 15013874]

136. Kim SY, Sadda S, Pearlman J, et al. Morphometric analysis of the macula in eyes with disciform age-related macular degeneration. Retina 2002;22:471-477. [PubMed: 12172115]

137. Green WR, Key SN 3rd. Senile macular degeneration: a histopathologic study. Trans Am Ophthalmol Soc 1977;75:180-254. [PubMed: 613523]

138. Penfold PL, Provis JM, Billson FA. Age-related macular degeneration: ultrastructural studies of the relationship of leucocytes to angiogenesis. Graefes Arch Clin Exp Ophthalmol 1987;225:70-76. [PubMed: 2436980]

139. Dastgheib K, Green WR. Granulomatous reaction to Bruch's membrane in age-related macular degeneration. Arch Ophthalmol 1994;112:813-818. [PubMed: 7516148]

140. Hageman GS, Luthert PJ, Victor Chong NH, Johnson LV, Anderson DH, Mullins RF. An integrated hypothesis that considers drusen as biomarkers of immune-mediated processes at the RPE-Bruch's membrane interface in aging and age-related macular degeneration. Prog Retin Eye Res 2001;20:705-732. [PubMed: 11587915]

141. Penfold PL, Madigan MC, Gillies MC, Provis JM. Immunological and aetiological aspects of macular degeneration. Prog Retin Eye Res 2001;20:385-414. [PubMed: 11286898]

142. Anderson DH, Mullins RF, Hageman GS, Johnson LV. A role for local inflammation in the formation of drusen in the aging eye. Am J Ophthalmol 2002;134:411-431. [PubMed: 12208254]

143. Chen J, Connor KM, Smith LE. Overstaying their welcome: defective CX3CR1 microglia eyed in macular degeneration. J Clin Invest 2007;117:2758-2762. [PubMed: 17909623]

144. Oka C, Tsujimoto R, Kajikawa M, et al. HtrA1 serine protease inhibits signaling mediated by Tgfbeta family proteins. Development 2004;131:1041-1053. [PubMed: 14973287]

145. Chan CC, Shen DF, Zhou M, et al. Human HtrA1 in the eyes with age-related macular degeneration. Trans Am Ophthalmol Soc 2007;105:92-98. [PubMed: 18427598]

146. Allikmets R, Dean D. Bringing age-related macular degeneration into focus. Nat Genet 2008;40:820-821. [PubMed: 18583975]

147. Tomany S, Wang J, van Leeuwen R, et al. Risk factors for incident age-related macular degeneration. Pooled findings from 3 continents. Ophthalmology 2004;111:1280-1287. [PubMed: 15234127]

148. The Alpha-Tocopherol, Beta Carotene Cancer Prevention Study Group. The effect of vitamin E and beta carotene and the incidence of lung cancer and other cancers in male smokers. N Engl J Med 1994;330:1029-1035. [PubMed: 8127329]

149. Omenn GS, Goodman GE, Thornquist MD, et al. Effects of a combination of beta carotene and vitamin A on lung cancer and cardiovascular disease. N Engl J Med 1996;334:1150-1155. [PubMed: 8602180]

150. Bjelakovic G, NIkolova D, Gluud LL, Simonetti RG, Gluud C. Mortality in randomized trials of antioxidant supplements for primary and secondary prevention: systematic review and metaanalysis. JAMA 2007;297:842-857. [PubMed: 17327526]

151. Albanes D. Letter to the editor. JAMA 2007;298:400. [PubMed: 17652290] 
152. Gluud LL, Bjelakovic G, Niklova D, Simonetti RG, Gluud C. Response from authors. JAMA 2007;298:402-403.

153. Huang HY, Teutsch S, Bass E. Letter to the editor. JAMA 2007;298:400-401. [PubMed: 17652289]

154. Miller ER III, Pastor-Barriuso R, Dalal D, Riemersma RA, Appel LJ, Guallar E. Meta-analysis: high dosage vitamin E supplementation may increase all-cause mortality. Ann Intern Med 2005;142:3746. [PubMed: 15537682]

155. Chew EY, Clemons T. Vitamin E and the Age-Related Eye Disease Study supplementation for agerelated macular degeneration. Arch Ophthalmol 2005;123:395-396. [PubMed: 15767485]

156. Complications of Age-Related Macular Degeneration Prevention Trail Research Group. Laser treatment in patients with bilateral large drusen: the complications of age-related macular degeneration prevention trial. Ophthalmology 2006;113:1974-1986. [PubMed: 17074563]

157. Owen SL, Bunce C, Brannon AJ, et al. Prophylactic laser treatment hastens choroidal neovascularization in unilateral age-related maculopathy: final results of the drusen laser study. Am J Ophthalmol 2006;141:276-281. [PubMed: 16458680]

158. Friberg TR, Musch DC, Lim JI, et al. Prophylactic treatment of age-related macular degeneration report number 1: 810-nanometer laser to eyes with drusen. Unilaterally eligible patients. Ophthalmology 2006;113:612-622.

159. Macular Photocoagulation Study Group. Argon laser photocoagulation for neovascular maculopathy. Three-year results from randomized clinical trials. Arch Ophthalmol 1986;104:694701. [PubMed: 2423061]

160. Macular Photocoagulation Study Group. Argon laser photocoagulation for senile macular degeneration: results of a randomized clinical trial. Arch Ophthalmol 1982;100:912-918. [PubMed: 7046707]

161. Treatment of Age-Related Macular Degeneration With Photodynamic Therapy (TAP) Study Group. Photodynamic therapy of subfoveal choroidal neovascularization in age-related macular degeneration with verteporfin. Two-year results of 2 randomized clinical trials-TAP report 2; Arch Ophthalmol. 2001. p. 198-207.

162. Verteporfin Roundtable 2000 and 2001 Participants, TAP study group principal investigators; VIP study group principal investigators. Guidelines for using verteporfin (visudyne) in photodynamic therapy to treat choroidal neovascularization due to age-related macular degeneration and other causes. Retina 2002;22:6-18. [PubMed: 11884872]

163. Gragoudas ES, Adamis AP, Cunningham ET, et al. Pegaptanib for neovascular age-related macular degeneration. N Engl J Med 2004;351:2805-2816. [PubMed: 15625332]

164. Rosenfeld PJ, Brown DM, Heier JS, et al. Ranibizumab for neovascular age-related macular degeneration. N Engl J Med 2006;355:1419-1431. [PubMed: 17021318]

165. Brown DM, Kaiser PK, Michels M, et al. Ranibizumab versus verteporfin for neovascular agerelated macular degeneration. N Engl J Med 2006;355:1432-1444. [PubMed: 17021319]

166. Steinbrook R. The price of sight-ranibizumab, bevacizumab, and the treatment of macular degeneration. N Engl J Med 2006;335:1409-1412. [PubMed: 17021315] 


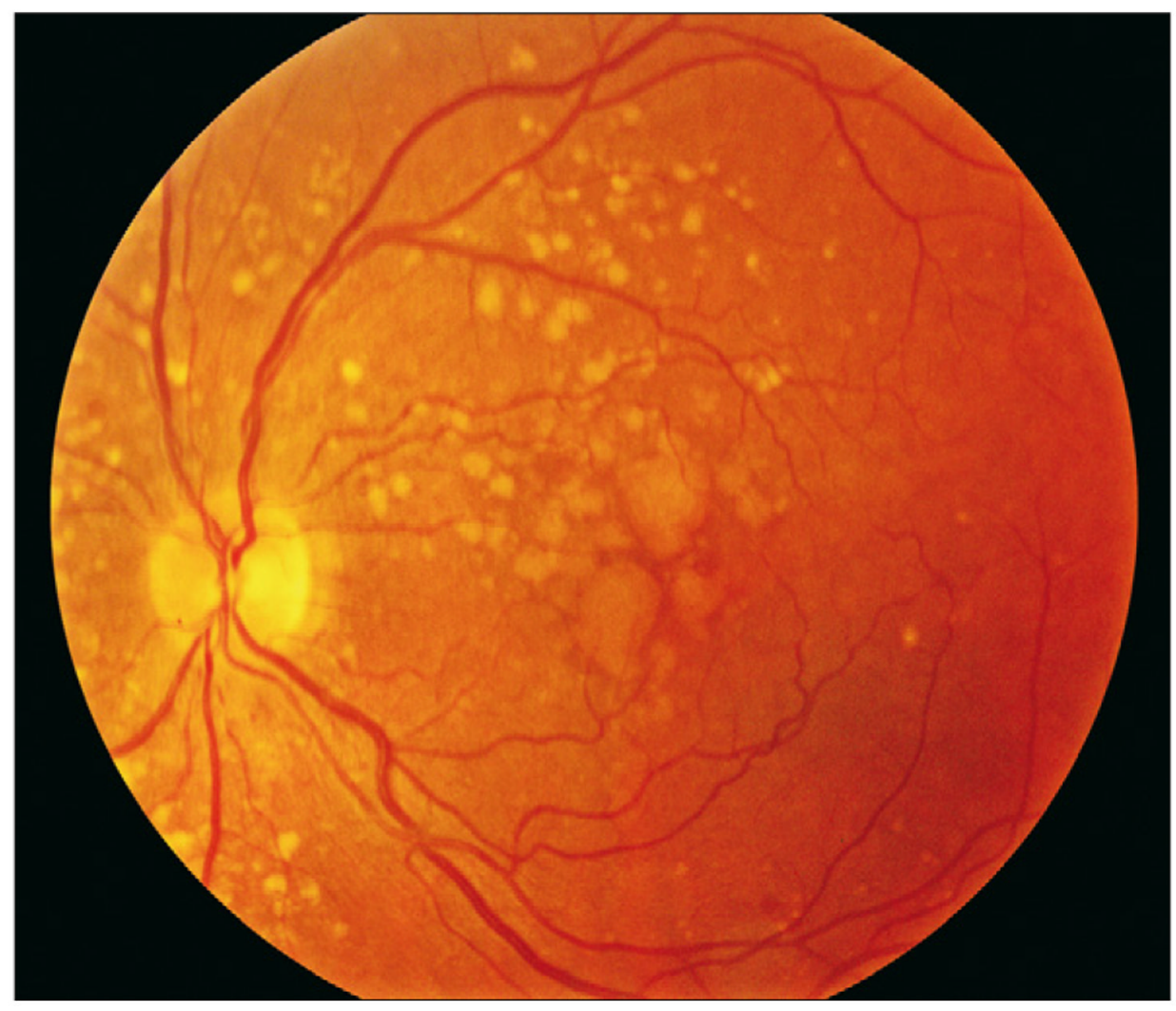

Figure 1.

Left eye of a patient with intermediate age-related macular degeneration with large drusen 


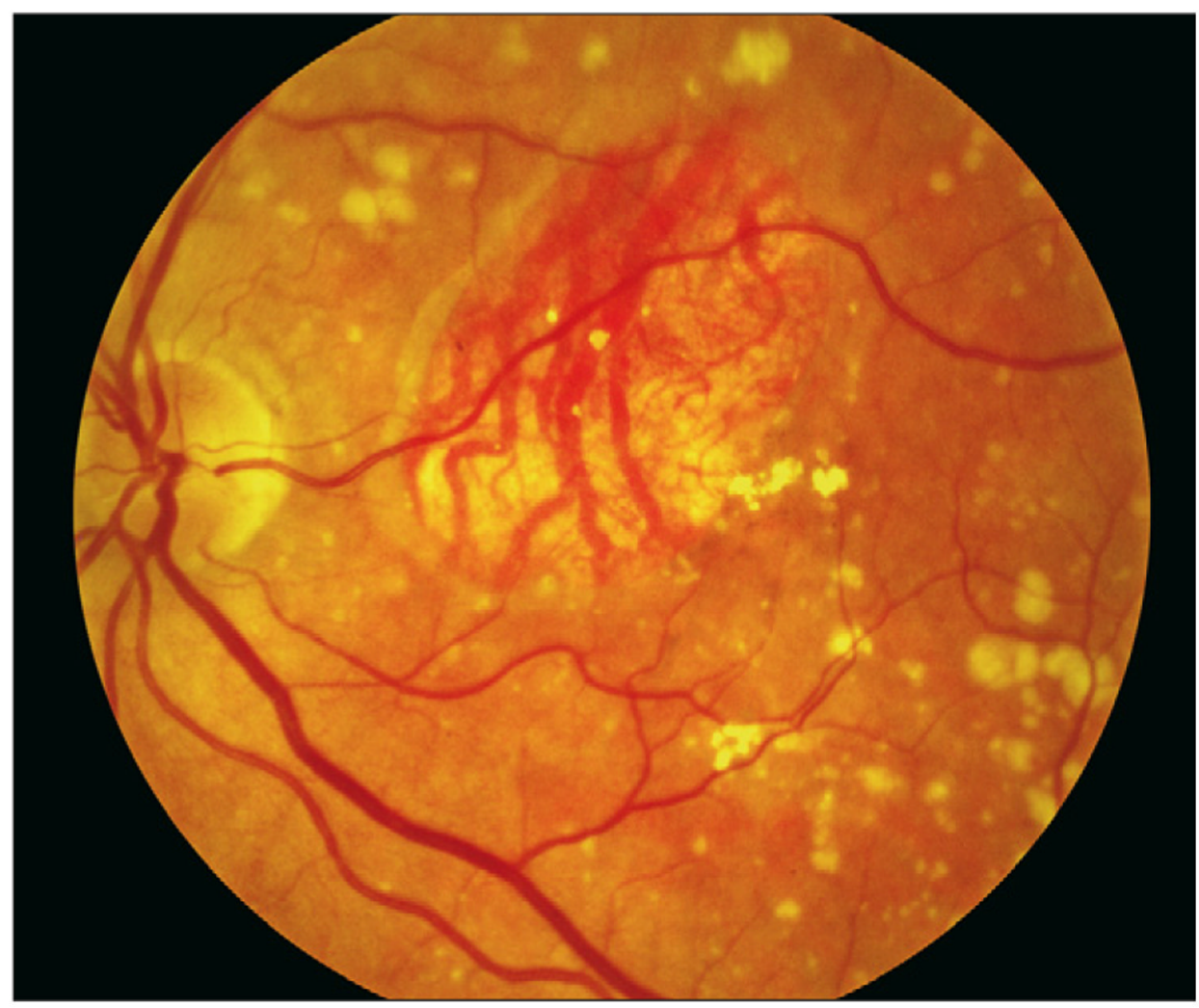

Figure 2.

Geographic atrophy involving the centre of the fovea, with sharply demarcated loss of normal retinal pigment epithelial cells and evidence of deeper larger choroidal vessels 


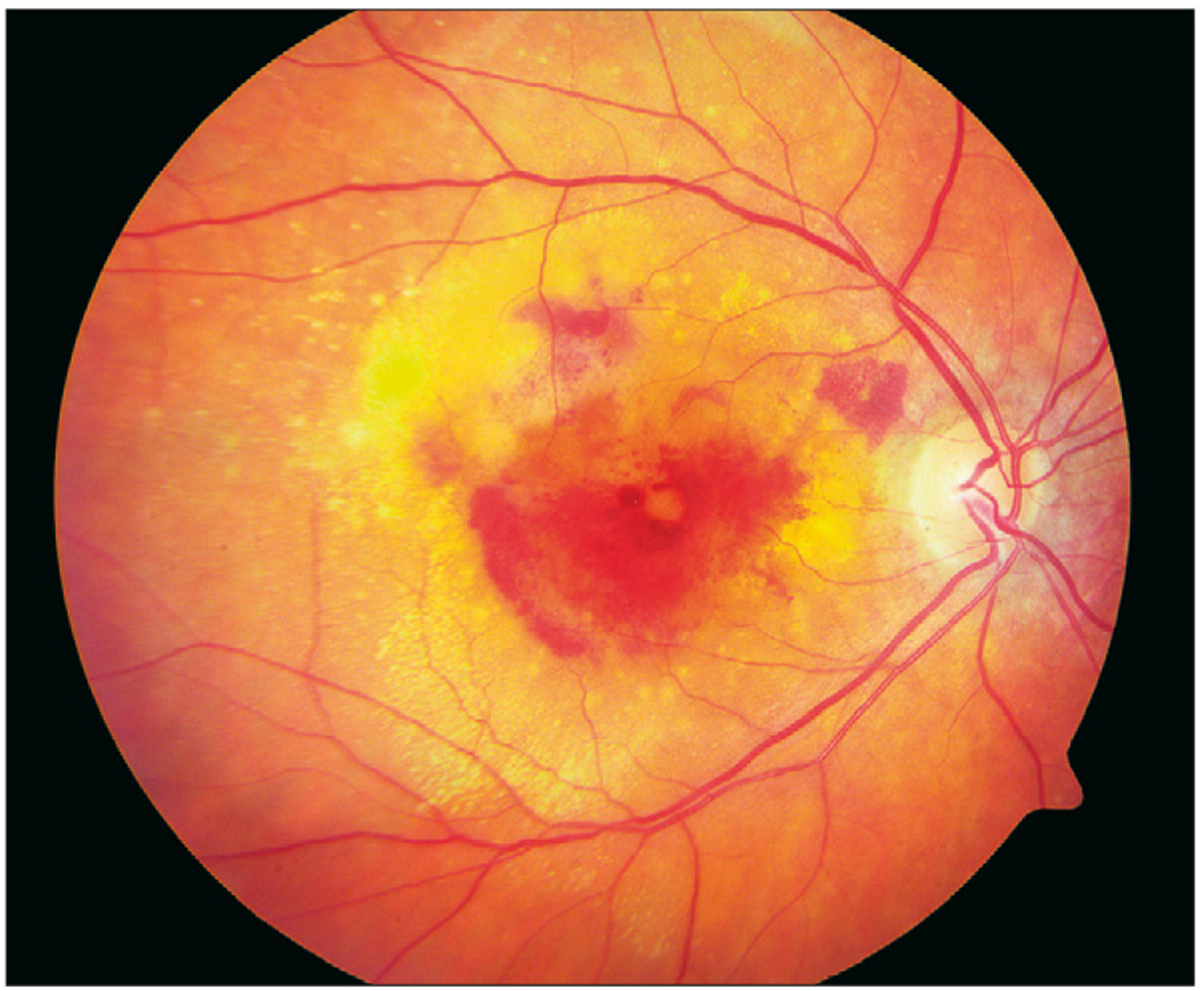

Figure 3.

Neovascular age-related macular degeneration, with retinal haemorrhage, lipids, or retinal hard exudate and subretinal fluid 


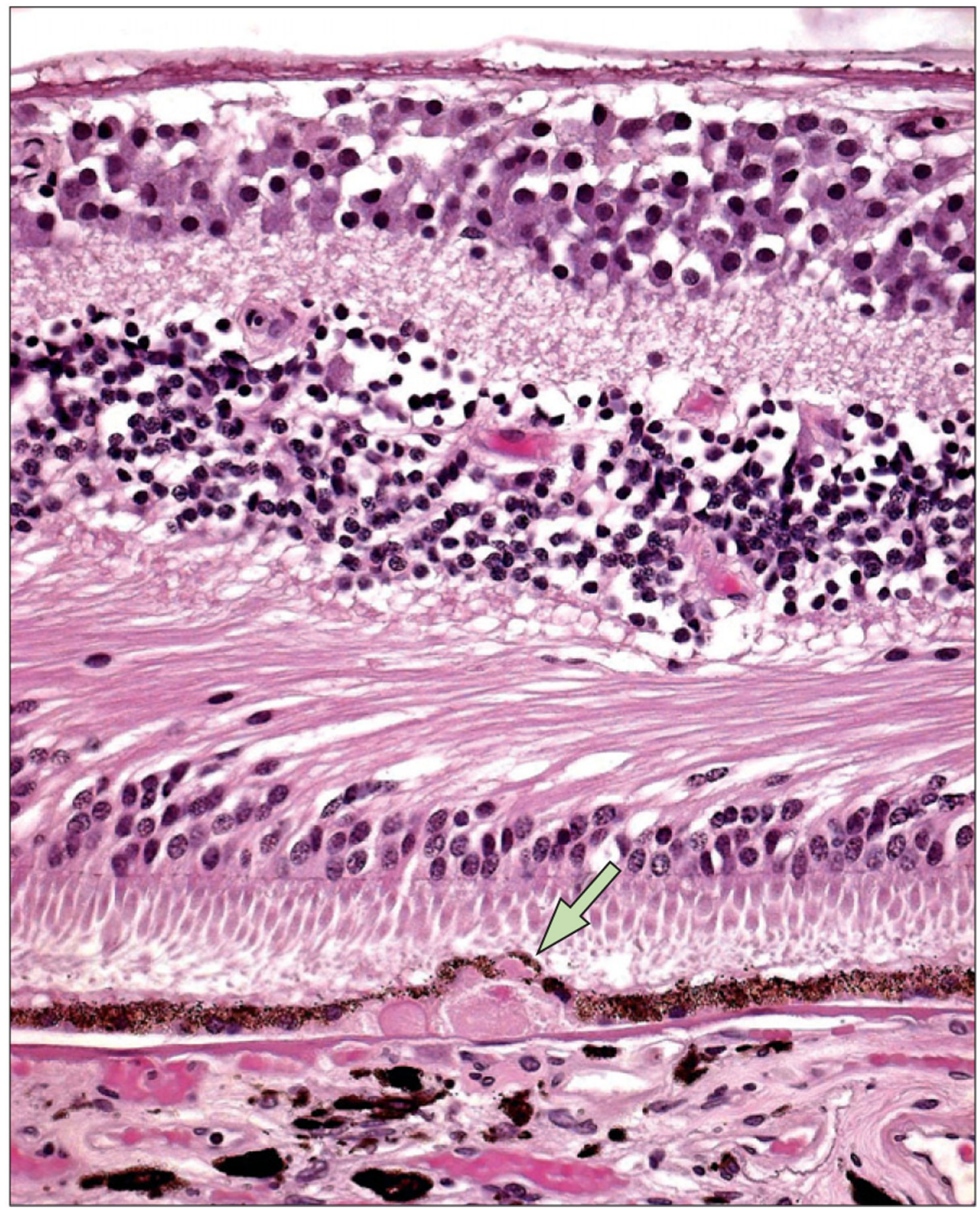

Figure 4. A typical large drusen (arrow) composed of hyaline deposits with granular ground substance from the inner aspect of Bruch's membrane

The underlying retinal pigment epithelium cells are thin and compressed. Photoreceptors appear to be mildly atrophied in an age-related macular degeneration eye. 


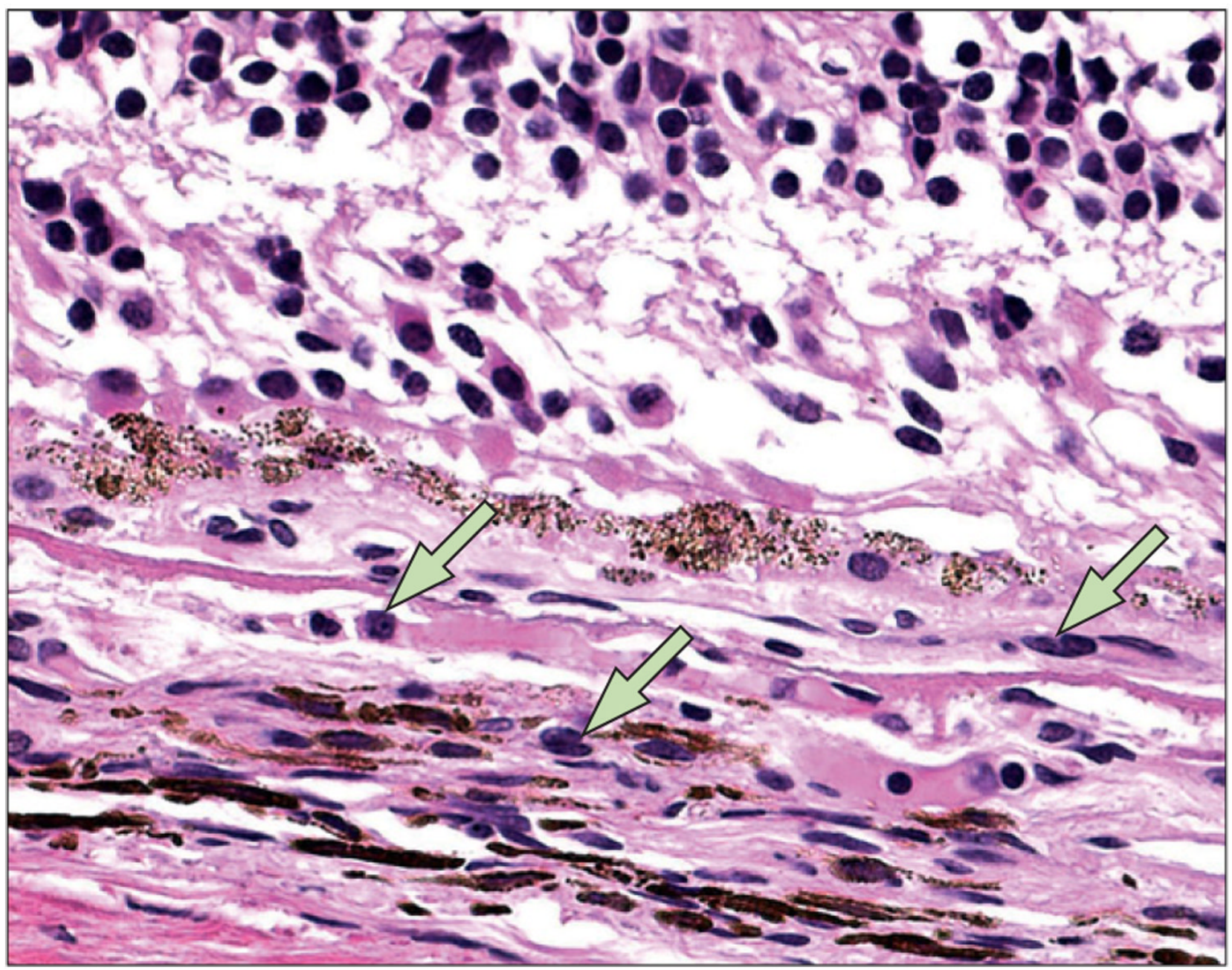

Figure 5.

Macrophages (arrows) in and surrounding a small choroidal neovascular lesion, with breaks at Bruch's membrane 


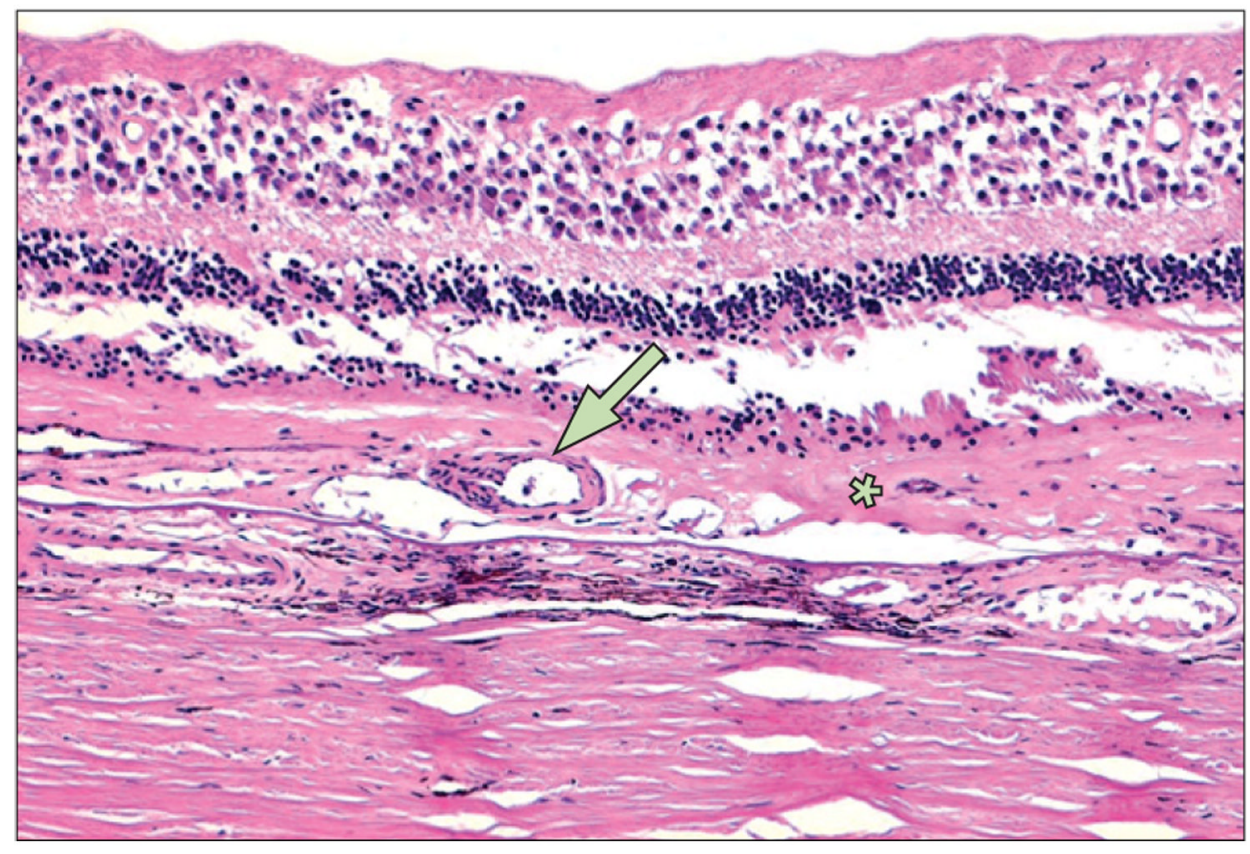

Figure 6.

Dense collagen fibrous tissue (asterisk) between the degenerative photoreceptor cells and Bruch's membrane and a large feeder vessel (arrow) penetrating through the macular scar 


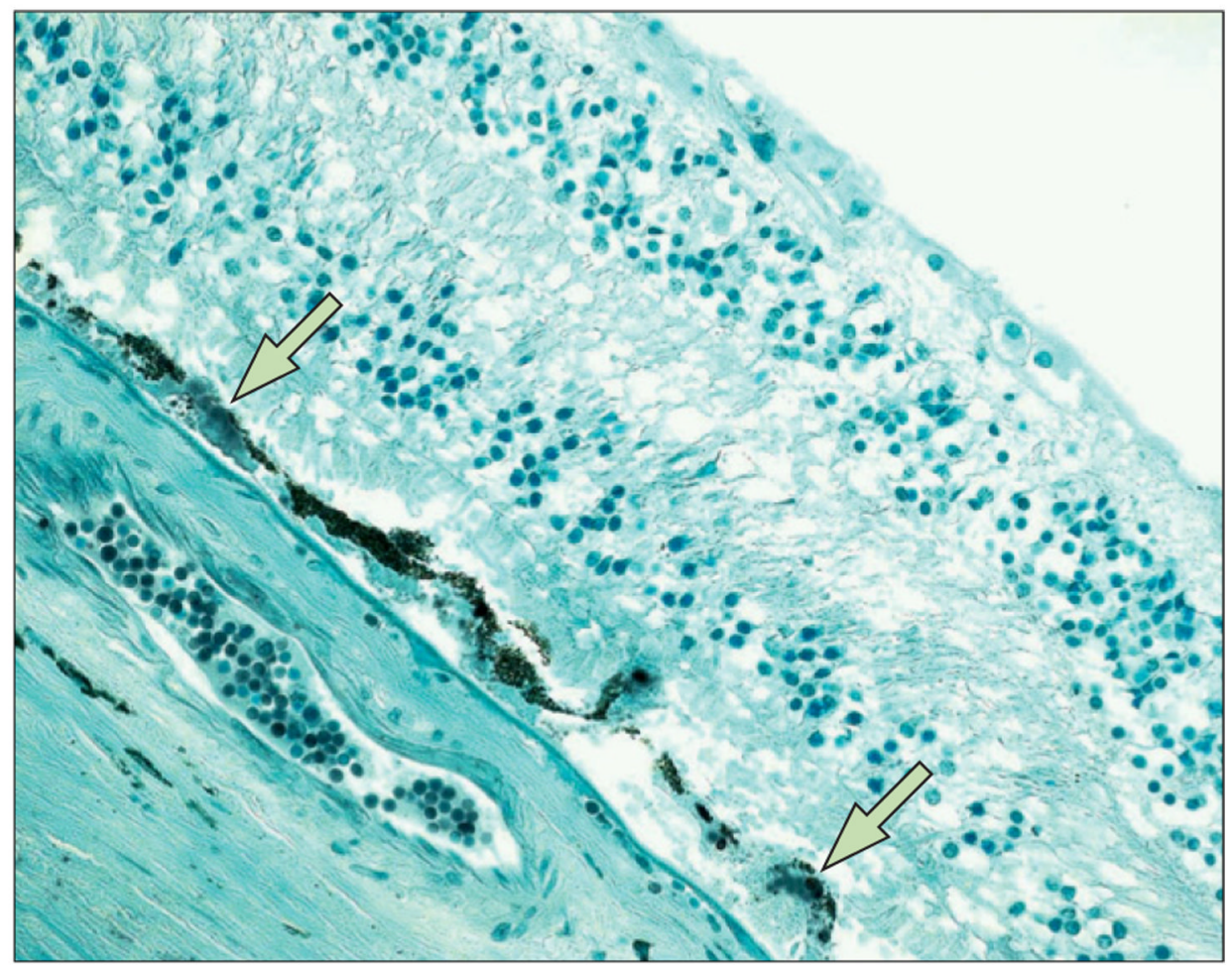

Figure 7.

Positive HtrA1 immunoreactivity (arrows) in soft drusen 